\title{
The Impact of Communicating Sustainability and Ethical Behaviour of the Cosmetic Producers: Evidence from Thailand
}

\author{
Hiroko Oe $^{1, *(\mathbb{D})}$ and Yasuyuki Yamaoka ${ }^{2}$ D \\ 1 The Business School, Bournemouth University, Poole BH12 5BB, UK \\ 2 Faculty of Society and Industry, The Open University of Japan, Chiba 261-8586, Japan; yamaoka-y@ouj.ac.jp \\ * Correspondence: hoe@bournemouth.ac.uk
}

check for updates

Citation: Oe, H.; Yamaoka, Y. The Impact of Communicating Sustainability and Ethical Behaviour of the Cosmetic Producers: Evidence from Thailand. Sustainability 2022, 14 , 882. https://doi.org/10.3390/ su14020882

Academic Editor: Lester Johnson

Received: 26 November 2021

Accepted: 10 January 2022

Published: 13 January 2022

Publisher's Note: MDPI stays neutral with regard to jurisdictional claims in published maps and institutional affiliations.

Copyright: (C) 2022 by the authors. Licensee MDPI, Basel, Switzerland. This article is an open access article distributed under the terms and conditions of the Creative Commons Attribution (CC BY) license (https:// creativecommons.org/licenses/by/ $4.0 /)$.

\begin{abstract}
Purpose-This study aims to demonstrate the antecedent factors of consumers' cosmetics purchasing behaviour in the emerging market of Thailand from the perspective of sustainability. Specifically, the study aims to quantitatively analyse the impact of three hypothesised antecedents of consumer behaviour: product quality, communicating sustainability, and ethical business behaviour. Methodology-A quantitative methodology is applied in the study, which collects survey data from Thailand. This study focuses on two cosmetic brands in Thailand, a domestic brand and an international brand. The total 800-sample dataset was analysed using Structural Equation Modelling to validate a conceptual model with measurements of three antecedent factors: quality, ethical behaviour, and communication sustainability. Findings-It is found that 'ethical behaviour of the producers had a non-significant impact for all samples and the 'domestic brand', whereas communicating sustainability had a significant impact in all sample cases. The proposed measurement scales present a practical and pioneering tool for assessing consumer responses and behaviour towards cosmetic brands. The set of scales will also help cosmetics marketers to appraise their strategic planning and monitor their progress toward creating and identifying consumer loyalty to cosmetics brands via producers' ethical behaviour and CSR messaging. Originality-The global market and inter-stakeholder communications have greatly changed the way people perceive, behave towards, and react to business suppliers. The understanding of consumer brand loyalty in the cosmetics industry and the business strategies focused on the impact of communicating sustainability with ethical behaviour remain limited, especially in the context of the emerging market. This research contributes to filling this gap with empirical analyses.
\end{abstract}

Keywords: product quality; communicating sustainability; ethical producer behaviour; consumer behaviour; structural equation modelling

\section{Introduction}

In an era marked by a concern for sustainable development, a closer investigation into the relationship between businesses that aim to sustain their operations through ethical behaviour and the consumers' responses to this behaviour is crucial in view of the desire to propose more actionable implications for both businesses and consumers. Many authors have noted that decision-making today is more complex than at any time in the past, especially given the vast array of different products with which consumers are confronted [1,2]. Meanwhile, the notion of corporate social responsibility (CSR) has become one of the most popular topics of discussion among academics and marketers alike, specifically in relation to its impact on consumer decision-making [3,4].

It is also important from a CSR perspective to disclose manufacturing processes and appropriate ingredient lists as evidence that a company is engaged in ethical business practices, as well as to ensure that consumers can use products safely and without risk to their health. While various academic discussions have outlined the clear implications here, these discussions have largely revolved around the international brands and consumer 
responses in the Western context [4,5]; by contrast, little attention has been paid to consumer responses to the ethical attributes of cosmetic products and business behaviour, especially in emerging markets.

It has been stipulated that a difference exists between the behaviour of consumers in emerging markets and those in mature markets in relation to CSR. In this regard, it is helpful to reflect on research suggesting that consumers' perceptions of CSR and their interest in ethical corporate behaviour change during the market maturation process [6,7].

Although there is a growing body of relevant research on emerging markets due to their growing populations and potential for expansion, further in-depth research is required to assess the feasibility of data collection and the priorities of companies. The results of this valuable empirical study based on data from an emerging market suggest that, in contrast to the Western view that CSR factors tend to have a strong influence on consumer purchasing behaviour, consumers in emerging markets do tend to be interested in and favour corporate CSR, but this interest tends not to lead to specific behavioural changes [6].

Given the potential size of the market in question, it is vital that companies develop strategies based on in-depth research into consumer behaviour in emerging markets. In particular, the impact of the ethical attributes of cosmetics on consumer behaviour is an important and urgent research topic for companies seeking to attract consumers in emerging markets and develop them as loyal customers. However, there is a lack of research on this subject in academia today, which has led to a lack of basic materials available for use in developing concrete marketing strategies.

In this study, we aim to fill this research gap, to investigate the antecedents that determine cosmetic choice behaviour in emerging countries from an ethical perspective, and to elucidate the associated consumer behaviour patterns. For this purpose, we select two different cosmetic brands-a 'domestic brand' and an 'international brand'-and decipher the different phases of consumers' evaluation of each brand along with their purchasing behaviour. By investigating the antecedent factors that may influence consumers' loyalty to a particular cosmetic product and developing an analytical framework characterised by practical measurement scales, we aim to contribute to future research on product choice behaviour in emerging economies by providing models and scales for analysing consumer behaviour in these contexts.

\section{Literature Review}

\subsection{Focus of the Study}

\subsubsection{Context: Thailand as an Emerging Market}

In order to make our research more informative, it is important to keep in mind the themes of the Thai cosmetics industry and consumer sentiment. For example, customers in Thailand, a representative emerging market, are known to exhibit tendencies and behaviours distinct from those in the same class of middle-developed countries. In this regard, for example, [7] found that while conspicuous value generally influences consumer willingness to pay for luxury goods, an analysis of survey data collected from Thai consumers showed that conspicuous value does not have a significant effect on purchasing behaviour. In an empirical study based on consumer data from Turkey, also an emerging market, it was found that consumers favourably perceive CSR actions taken by companies, but that this does not necessarily lead to specific purchasing behaviour [6].

Thus, although the impact of CSR and other ethical corporate strategies on consumer behaviour is generally agreed upon and confirmed in the international context, further research into emerging markets is required. It is understood that Thai consumer behaviour is impacted by the attachment to, pride in and respect for one's own culture and traditions embedded in the mindset of Thai people [8-10]. Some empirical research has been conducted based around datasets obtained from a variety of emerging markets [11-13]. However, analytical conclusions on this subject tend to vary such as those related to, e.g., the impact of CSR behaviour. In the business field-including the specific area of cosmetic purchasing behaviour, the subject of this study-empirical research into CSR among consumers in 
emerging countries is particularly lacking with regard to comparisons between home and international brands. The issues addressed by this study may accordingly contribute to stimulating further debate in the relevant fields.

\subsubsection{Research Target: Cosmetics in Thailand}

Thailand has a distinctive demographic composition among emerging countries, with a relatively high proportion of Gen-Y and Gen-Z. This means that the population aged between 10-20 years old is currently driving economic activity and consumption in Thailand, a trend that is expected to continue for some time to come [14].

Thailand is also known to be a highly educated country, due to a policy of limiting childbirths introduced in 1970 and the increasing participation of women in society, which has led to an increased preference for higher education to ensure the future of a smaller number of children [15]. The educational level of Thai workers has also shown distinctive trends. For example, in the four years from 2012 to 2016, the proportion of workers with a primary education or lower decreased by $5.6 \%$, while the proportion with a university degree or higher increased by $3.8 \%$ across Thailand [14]. The trend towards higher education is particularly noticeable in urban areas, where the proportion of workers with a university degree or higher is much greater: according to Thailand's most recent available data, as of 2019 , the proportion of the labour force that is highly educated (as a percentage of the total labour force) is indicated at $82.8 \%$ [14].

Therefore, this study focused specifically on Thai consumers belonging to younger generations with a higher educational background as a leading consumer segment in commodity consumption, aiming to examine and understand the latest market trends in cosmetics consumption, which is a key theme of the study.

Previous research has shown that young consumers are more interested in the ethical aspects of business and are more likely to focus on a company's CSR strategy and the ethical value of its manufacturing processes when making a purchase. However, related research in emerging markets remains insufficient. It would therefore be useful to quickly conduct research into the behaviour of younger and more educated consumers, who are considered to be particularly sensitive to CSR, in order to improve business ethics around sustainable consumer behaviour and the responsible production of everyday products. This is also important from the perspective of improving business ethics around sustainable consumer behaviour and the responsible production of everyday products.

\subsection{Quality: Ethical Sources and Consumer Experiences}

Manufacturing technology is one of the key issues for cosmetics producers. Retailers and manufacturers have partnered with supply chain technology organisations to support their visibility and success throughout the cosmetics supply chain [16]. The cosmetics sector has attempted to implement the technology required to secure ethical sources and ensure that ingredient safety standards are met [17]. Ref. [18] developed and presented a framework for cosmetics consumers' satisfaction with cosmetics brands, including the products' quality. Moreover, young adult consumers are regarded as the most significant consumer segment in relation to ethical and sustainable consumption [19], which suggests that cosmetics producers and retailers should focus more on the ethical attributes of their products and the ethical behaviour of cosmetics suppliers [20]. As an advanced technology, blockchain technology has also helped to improve supply chain visibility and support ethical sourcing [21].

Having recognised the change in markets driven by technological innovation, cosmetics manufacturers have subsequently formed partnerships with ICT specialists to improve the consumer experience and enhance their operations [22]. A crucial element here is that of analysing product popularity-related data that are based on ingredients and sources. By adapting to this change in the market, a business can enhance its productivity and longevity through the implementation of a digital retailer strategy, use of meaningfully 
ethical ingredients, and the adoption of fair processing procedures throughout the supply chain network before the products are delivered to the end consumers [1].

The 1223/2009/EK Decree of the European Union requires cosmetics producers to collate and evaluate reports on the disadvantages of the cosmetic products they sell [23]. The EU regulatory framework also emphasises the importance of highly problematic nondesired effects, with guidelines encouraging European cosmetics manufacturers to develop effective strategies to prevent or mitigate these effects in order to remain compliant with the legal requirements for operating a cosmetics business. However, no such scheme exists in the East Asian region; the relevant discussions and experiences in Europe have shed some light on these sectors. For the analytical model, three potential variables are developed regarding the quality of the products, ethical sourcing and consumers' brand loyalty [24-31]. Based on the above discussion, the first hypothesis is as follows:

Hypothesis 1 (H1). Quality, ethical sourcing, and production processes have an impact on consumer loyalty towards cosmetic products.

\subsection{Communicating Sustainability}

Brand loyalty reflects the likelihood that a customer will make a repeat purchase or decide to switch to another brand, especially when the original brand undergoes a change [32,33]. Ref. [34] emphasised that businesses need to improve their ability to attract consumers through what they termed 'the new brand spirit'.

Advertising is a commonly used method of attracting consumers and ensuring their loyalty. Ref. [35] investigated the impact of ethical advertising on consumer loyalty and found that its positive impact results in repeat purchases. It can therefore be argued that brand attachment and consumers' positive attitudes towards a brand are largely related to the perceived quality of its products [36]. However, focusing on the cosmetics sector, [37] used empirical analysis to determine that only corporate authenticity has a positive effect on brand attachment and consumer loyalty; accordingly, the authors suggested that marketing strategies should be designed based on CSR activities that effectively demonstrate corporate authenticity. Elsewhere, following an analysis of the corporate messages on companies' websites, [38] asserted that the communication of sustainable business behaviour is a key factor behind consumer loyalty.

The concept of consumer engagement and consumer behaviour in brand communities is a popular research topic in the field $[39,40]$. Moreover, in the more recently established academic arena of social responsibility and consumers' responses, the relationships between 'communicating sustainability' and 'brand loyalty' or consumer engagement have been explored in a variety of contexts and markets. It is always critical to examine the latest patterns of consumer behaviour in the most recent situation and conditions [41,42]; however, most existing research has focused on consumer engagement within brand communities on social media platforms.

Therefore, further discussions in the broader context of market perspectives could be enhanced by expanding the research focus to include arenas outside of social media platforms. Based on the discussions above, the second hypothesis is as follows:

Hypothesis 2 (H2). Communicating sustainability has an impact on consumers' loyalty towards cosmetic products.

\subsection{Ethical Behaviour of Producers}

Thailand is an example of an emerging market in which both the economy and consumer behaviour have been undergoing transitions, with a variety of goods and services on offer that bear an array of brand names and are imported from numerous countries [43]. Due to the huge increase in available consumer choices and the changes in consumer needs and desires, competition in the cosmetics market has become fiercely intense. In light of this, it is crucial that firms understand the factors affecting consumers' purchasing 
behaviour [44]. Specifically, it is important to identify distinct triggers that will enhance ethical consumption, along with the response to companies' ethical behaviour within the marketing context. Ref. [45] empirically investigated consumers' reactions to animal-tested cosmetic products to evaluate the impact of ethical manufacturer behaviour.

In terms of the cosmetics industry, the behaviours of Asian consumers tend to be vastly different from those in the West; this is especially true in Thailand, due to the numerous differences in culture, physicality, and lifestyle $[46,47]$. Here, the consumer behaviour model devised by [48] helps to explain how a large number of factors can influence consumption and which relevant behaviours are implicated. The discussion suggests that higher (or lower) levels of ethical behaviour by cosmetics providers can be associated with higher (or lower) loyalty.

Regarding the analytical model, three variables were developed in the context of brands' ethical behaviour and consumers' loyalty based on the relevant academic discussions [49-55].

Based on the above discussion, the third hypothesis is as follows:

Hypothesis 3 (H3). The ethical behaviour of producers has an impact on consumers' brand loyalty towards cosmetic products.

\subsection{Consumer Decisions and Brand Loyalty}

Ref. [56] defined motivation as a basic concept of human behaviour that drives an individual to take a particular action; in other words, motivation refers to the processes that initiate, guide and maintain goal-oriented behaviour [57]. Ref. [58] suggested that potential attendant factors and consequences of specific behaviours are not definitively determined and are both extremely complicated and interrelated. This conclusion has been reiterated by an extensive body of academic material, for example, by [59] in their study based on different datasets from various markets. In another academic source, [60] discussed consumer behaviour towards eco-friendly cosmetic products.

The interactive relationships among the factors underpinning consumers' satisfaction, decision making, and brand loyalty have been discussed and examined by numerous scholars [61-63]. The consumer's final decision generally involves various stages and elements driven by specific influential factors. In short, consumer behaviour does not represent a linear process. In line with this discussion, [64] also emphasised the benefits of quality management and effective communication with customers to attract more consumers in the markets. Regarding the analytical model, three variables were developed based on academic sources representing brand loyalty measurements [65-71].

Based on the above discussion, the fourth hypothesis on the theme of co-variant relationships for three antecedent factors leading to brand loyalty emerges as follows:

Hypothesis 4 (H4). The three main influential factors—quality, communicating sustainability, and ethical behaviour - have interactive relations.

\subsection{Conceptual Model with Hypothesised Relationships}

In summary, the theoretical arguments underpinning each latent factor and their relationships are listed below in Table 1 .

Based on the literature review in developing measurements for hypotheses, a model was designed that includes the three main influential factors, namely quality, communicating sustainability, and the ethical behaviour of producers, to be tested and validated using primary data-based analysis. As the figure shows, these three factors are regarded as interrelated, with the attendant relationships converging to result in brand loyalty. 
Table 1. Hypotheses and Supporting Discussions.

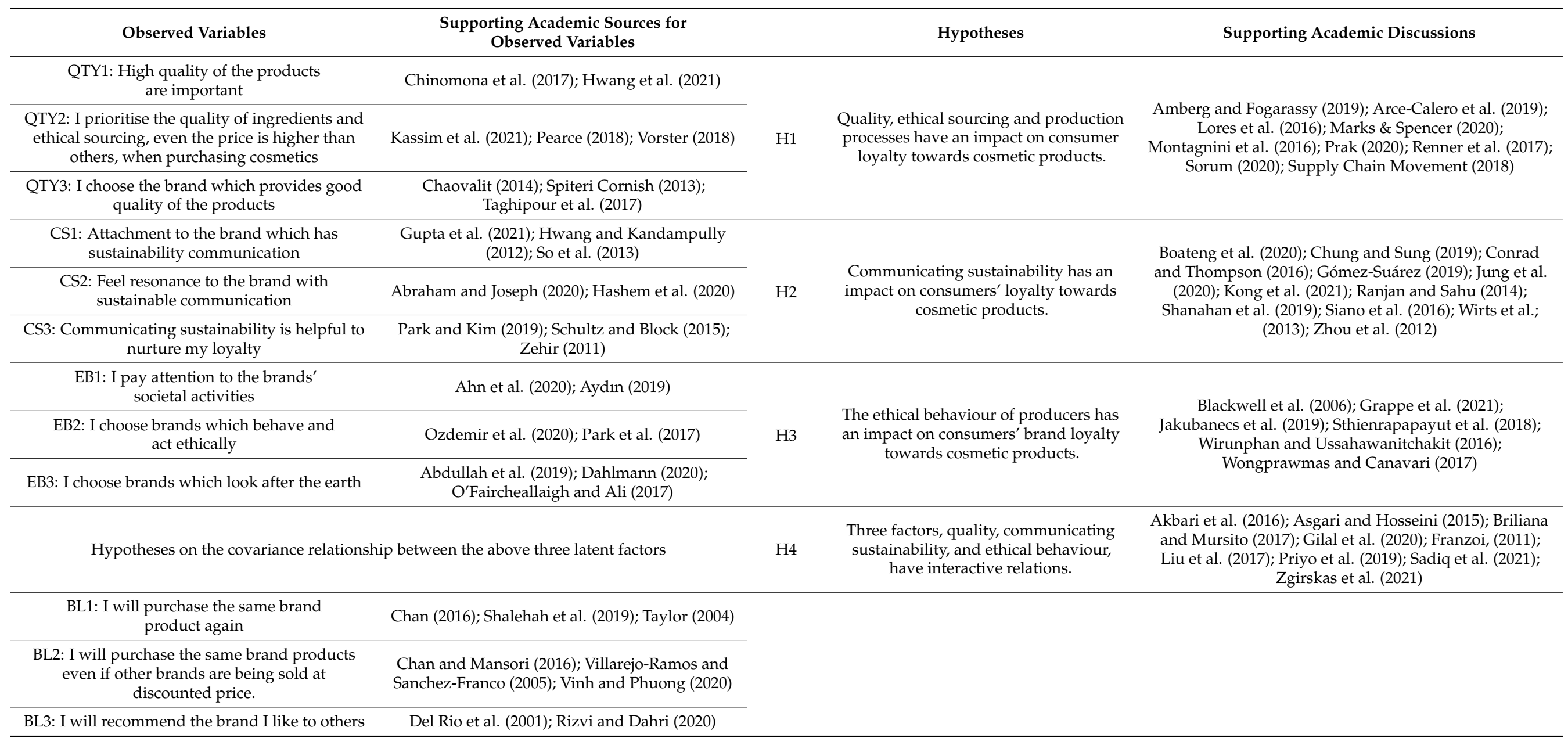


H1 focuses on the quality of the sourced ingredients (where quality is assessed in part based on the transparency and accountability of the sourcing process). Quality should be one of the key factors leading to consumer loyalty, as it is one of the established antecedents of brand loyalty among purchasers of cosmetics, food and beverages. The proposed model includes three such antecedents: quality, communicating sustainability, and ethical behaviour. By including the interactive relations among these three antecedent factors, the analysis has revealed the impact of the three factors on consumers' brand loyalty from a holistic perspective.

\section{Methodology}

\subsection{Research Approach}

The aim of the present research was to test and validate a conceptual model in view of the examination of the hypotheses developed from the literature review, with measurements related to a dataset collected from Thailand; thus, this study applies a quantitative approach [72]. The study involves the use of the survey method, specifically collecting data via questionnaire. This method is widely used, as it facilitates the collection of a large number of data from various sample groups [72,73].

\subsection{Survey Design}

In total, 26 items related to our hypotheses were prepared. Following a pilot test that was carried out with 12 volunteers, some modifications were made to the wording and the format before the main survey. The survey was conducted using a web-based survey service, SurveyMonkey, which allowed us to collect primary data from Bangkok, Thailand. The questions and corresponding options used in this research were carefully defined based on the key findings from the academic sources, following the model shown in Figure 1. The original survey questions were prepared in English before a bilingual individual translated them into Thai. A second bilingual individual, who had not seen the originals, subsequently back-translated the items into English before a third bilingual individual checked the translations. Throughout this process, any inconsistencies that emerged were discussed and resolved in order to finalise the questionnaire. This procedure was carried out with reference to $[74,75]$ to ensure the cultural and language equivalency of the scales being used.

To validate the scales, the dataset was analysed via factor analysis, Cronbach's alpha tests, and correlation analysis before the model was validated, with the dataset being utilised to examine the hypotheses using structural equation modelling (SEM).

\subsection{Data Collection and Analysis}

The questionnaire was distributed via electronic means (i.e., email and social network services) to a sample of 800 participants. The sample encompassed a wide range of age groups and both genders. All participants were residing in Bangkok, Thailand. The sample size was deemed suitable for conducting both the factor analysis and the subsequent SEM analysis [76]. SPSS version 26 was used for the data analysis, which was initially based on a descriptive analysis aimed at providing an overview of the dataset profile; this was followed by a relational analysis that incorporated factor analysis along with all the relevant observed variables. To test the reliability of the generated factors for further analysis, a Cronbach's alpha test was conducted to validate each factor and variable $[77,78]$. Correlation analysis was also carried out to assess the multi-collinearity of the independent variables among the factors and confirm that they were suitable for the SEM analysis [79], which was conducted using AMOS version 26. 


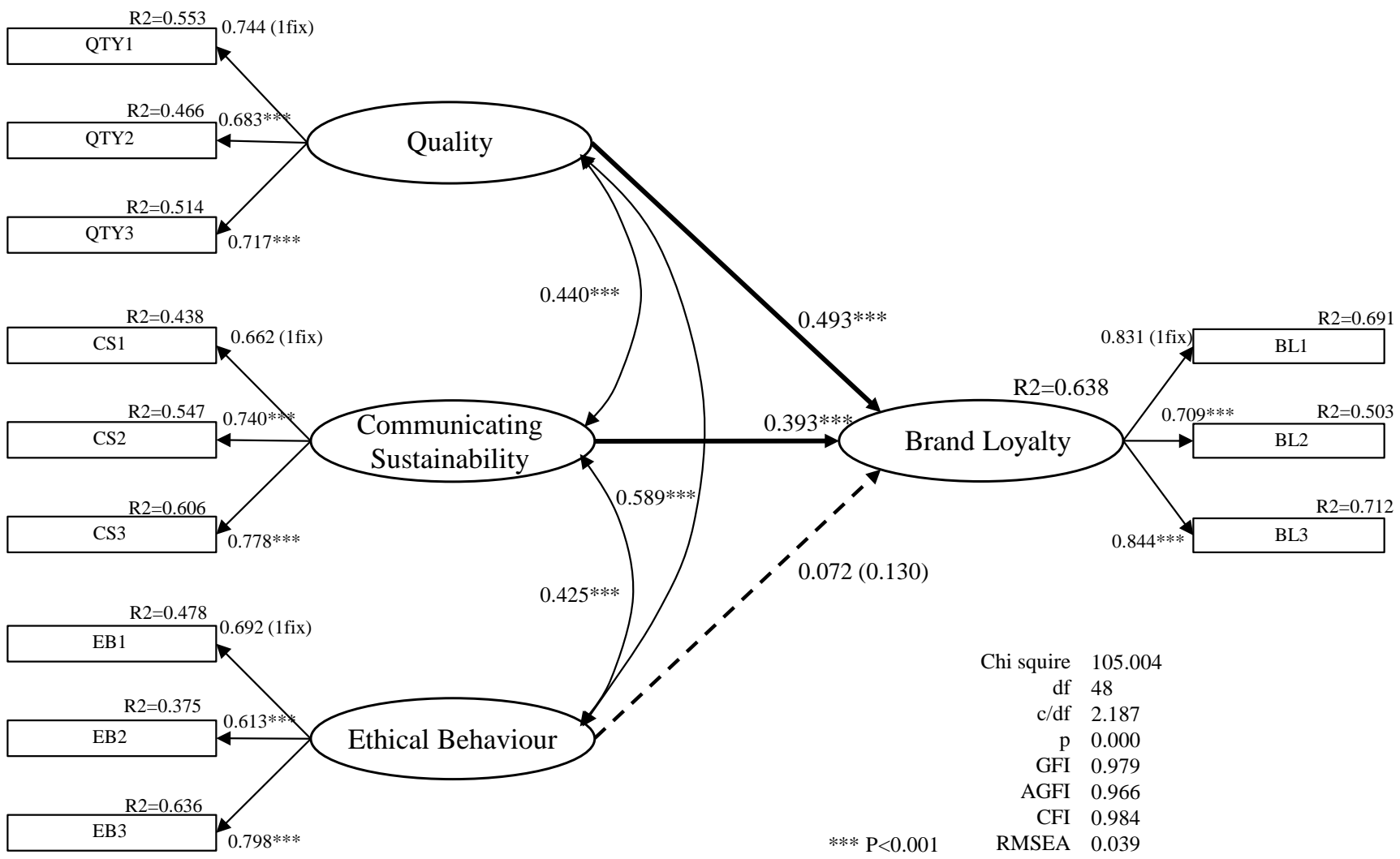

Figure 1. SEM analysis results (across the sample of 800).

\section{Results and Discussion}

\subsection{Data Profile}

4.1.1. Descriptive Statistics

Table 2 shows the demographic profile of the sample of 800 individuals. Overall, women accounted for $78 \%$ of the total sample, which corresponds to the brand's target demographic, while only around $22 \%$ of the sample were men. The average respondent age in our sample was 30.1 years old; moreover, $64.9 \%$ were single, while $33.6 \%$ were married or common-law married.

Table 2. Demographic profile.

\begin{tabular}{ccccc}
\hline Attribute & Frequency & Valid Percent & $\begin{array}{c}\text { Cumulative } \\
\text { Percent }\end{array}$ \\
\hline \multirow{2}{*}{ Gender } & Female & 628 & 78.5 & 78.5 \\
& Male & 172 & 21.5 & 100.0 \\
& Total & 800 & 100.0 & \\
\hline Age & $10 \mathrm{~s}$ & 18 & 2.3 & 2.3 \\
& $20 \mathrm{~s}$ & 474 & 59.5 & 61.7 \\
& $30 \mathrm{~s}$ & 212 & 26.6 & 96.3 \\
& $40 \mathrm{~s}$ & 64 & 8.0 & 99.9 \\
& $50 \mathrm{~s}$ & 28 & 3.5 & 100.0 \\
& $60 \mathrm{~s}$ & 1 & 0.1 & \\
& Missing & 3 & & 64.9 \\
& Total & 800 & 64.9 & \\
\hline \multirow{2}{*}{ Marriage status } & Single & 519 & 33.6 & \\
& Married & 269 & 1.5 & \\
& Missing & 12 & & \\
& Total & 800 & & \\
\hline
\end{tabular}


Table 2. Cont.

\begin{tabular}{|c|c|c|c|c|}
\hline Attribute & & Frequency & Valid Percent & $\begin{array}{c}\text { Cumulative } \\
\text { Percent }\end{array}$ \\
\hline \multirow[t]{6}{*}{ Education } & Secondary & 38 & 4.8 & 4.8 \\
\hline & Undergraduate & 596 & 74.9 & 79.6 \\
\hline & Postgraduate & 148 & 18.6 & 98.2 \\
\hline & Others & 14 & 1.8 & 100.0 \\
\hline & Missing & 4 & & \\
\hline & Total & 800 & & \\
\hline \multirow[t]{9}{*}{ Occupation } & $\begin{array}{c}\text { Company } \\
\text { worker }\end{array}$ & 418 & 52.4 & 52.4 \\
\hline & Business owner & 134 & 16.8 & 69.2 \\
\hline & Government & 48 & 6.0 & 75.2 \\
\hline & Student & 108 & 13.5 & 88.7 \\
\hline & Housewife & 24 & 3.0 & 91.7 \\
\hline & Other & 40 & 5.0 & 96.7 \\
\hline & Unemployed & 26 & 3.3 & 100.0 \\
\hline & Missing & 2 & & \\
\hline & Total & 800 & & \\
\hline \multirow[t]{8}{*}{ Income } & Under $15 \mathrm{~K}$ & 180 & 22.6 & 22.6 \\
\hline & $15 \mathrm{~K}-25 \mathrm{~K}$ & 286 & 35.8 & 58.4 \\
\hline & $25 \mathrm{~K}-35 \mathrm{~K}$ & 150 & 18.8 & 77.2 \\
\hline & $35 \mathrm{~K}-45 \mathrm{~K}$ & 74 & 9.3 & 86.5 \\
\hline & $45 \mathrm{~K}-50 \mathrm{~K}$ & 32 & 4.0 & 90.5 \\
\hline & Over $50 \mathrm{~K}$ & 76 & 9.5 & 100.0 \\
\hline & Missing & 2 & & \\
\hline & Total & 800 & & \\
\hline
\end{tabular}

More detailed descriptive statistics for the dataset are shown in Table 3. This table divides the sample into two groups of 400-one for the 'Domestic brand' answers and one for the 'International brand' answers-and identifies the different tendencies for each observed variable. Moreover, the common method bias (CMB) was tested, and the result was $35.12 \%$; this is less than $50 \%$ of the value specified by $[80,81]$, indicating no CMB issues.

Table 3. Descriptive statistics for the two sample groups, 'Domestic brand' and 'International brand'.

\begin{tabular}{|c|c|c|c|c|c|c|c|c|c|}
\hline \multirow[b]{2}{*}{ Observed Variables } & \multicolumn{3}{|c|}{ All Samples } & \multicolumn{3}{|c|}{ Domestic Brand } & \multicolumn{3}{|c|}{ International Brand } \\
\hline & $\mathbf{N}$ & Mean & Std. Dev. & $\mathbf{N}$ & Mean & Std. Dev. & $\mathbf{N}$ & Mean & Std. Dev. \\
\hline BL1: I will purchase the same brand product again & 800 & 2.63 & 1.01 & 400 & 2.70 & 0.99 & 400 & 2.56 & 1.04 \\
\hline BL2: I will purchase the same brand products even if & 800 & 2.78 & 0.99 & 400 & 2.91 & 0.95 & 400 & 2.65 & 1.01 \\
\hline BL3: I will recommend the brand I like to others & 800 & 2.91 & 0.98 & 400 & 3.04 & 0.92 & 400 & 2.78 & 1.02 \\
\hline $\begin{array}{l}\text { CS1: Attachment to the brand which has } \\
\text { sustainability communication }\end{array}$ & 800 & 3.13 & 0.91 & 400 & 2.94 & 0.85 & 400 & 3.31 & 0.93 \\
\hline $\begin{array}{l}\text { CS2: Feel resonance to the brand with } \\
\text { sustainable communication }\end{array}$ & 800 & 3.00 & 0.91 & 400 & 2.89 & 0.91 & 400 & 3.11 & 0.91 \\
\hline $\begin{array}{c}\text { CS3: Communicating sustainability is helpful to } \\
\text { nurture my loyalty }\end{array}$ & 800 & 3.19 & 0.84 & 400 & 3.18 & 0.84 & 400 & 3.19 & 0.84 \\
\hline QTY1: High quality of the products are important & 800 & 3.36 & 1.08 & 400 & 3.80 & 0.93 & 400 & 2.93 & 1.05 \\
\hline $\begin{array}{l}\text { QTY2: I prioritise the quality of ingredients and ethical } \\
\text { sourcing, even the price is higher than others, when } \\
\text { purchasing cosmetics }\end{array}$ & 800 & 3.08 & 1.02 & 400 & 3.39 & 0.96 & 400 & 2.77 & 0.98 \\
\hline $\begin{array}{c}\text { QTY3: I choose the brand which provides good quality } \\
\text { of the products with clear discription } \\
\text { and accountability }\end{array}$ & 800 & 3.16 & 0.95 & 400 & 3.39 & 0.88 & 400 & 2.93 & 0.97 \\
\hline EB1: I pay attention to the brands' societal activities & 800 & 2.97 & 0.84 & 400 & 3.05 & 0.82 & 400 & 2.90 & 0.86 \\
\hline EB2: I choose brands which behave and act ethically & 800 & 3.22 & 0.91 & 400 & 3.28 & 0.92 & 400 & 3.16 & 0.89 \\
\hline EB3: I choose brands which look after the earth & 800 & 3.07 & 0.94 & 400 & 3.08 & 0.95 & 400 & 3.06 & 0.93 \\
\hline
\end{tabular}

As discussed in the above literature review, the primary focus of this study is on the cognition and behaviour of the highly educated and relatively young generation in the Thai market, as this demographic represents the driving force behind purchasing behaviour. Therefore, a large proportion of respondents had undergraduate or postgraduate education 
(as demonstrated in Table 3), which indicates that the sample is skewed towards high education levels. This aspect needs to be carefully considered and properly reflected upon in the discussion while attempting to generalise the findings of the study. The attributes of the dataset will be discussed further below in the context of the study limitations and future research opportunities.

\subsubsection{Confirmatory Factor Analysis and Reliability of the Scales}

Confirmatory factor analysis was conducted for all samples. The results indicate the confirmation of the four specific factors, as shown in Table 4. The Cronbach's alphas for the four factors were $0.836,0.758,0.769$, and 0.745 , respectively; with all alpha values greater than 0.7 , the validity and reliability of the factors were confirmed [82].

Table 4. Factor analysis results.

\begin{tabular}{|c|c|c|c|c|c|}
\hline \multirow{2}{*}{ Observed Variables } & \multicolumn{4}{|c|}{ Component } & \multirow{2}{*}{ Alpha } \\
\hline & 1 & 2 & 3 & 4 & \\
\hline BL1: I will purchase the same brand products again & 0.820 & 0.157 & 0.181 & 0.114 & \\
\hline $\begin{array}{l}\text { BL2: I will purchase the same brand products even if } \\
\text { other brands are selling at discounted price. }\end{array}$ & 0.810 & 0.231 & 0.227 & 0.172 & 0.836 \\
\hline BL3: I will recommend the brand I like to others & 0.722 & 0.286 & 0.330 & 0.174 & \\
\hline $\begin{array}{l}\text { CS1: Attachment to the brand which has } \\
\text { sustainability communication }\end{array}$ & 0.101 & 0.807 & 0.044 & 0.148 & \\
\hline $\begin{array}{l}\text { CS2: Feel resonance to the brand with } \\
\text { sustainable communication }\end{array}$ & 0.192 & 0.793 & 0.140 & 0.090 & 0.758 \\
\hline $\begin{array}{l}\text { CS3: Communicating sustainability is helpful to nurture } \\
\text { my loyalty }\end{array}$ & 0.263 & 0.774 & 0.129 & 0.097 & \\
\hline QTY1: High quality of the products are important & 0.130 & 0.046 & 0.821 & 0.158 & \\
\hline $\begin{array}{c}\text { QTY2: I prioritise the quality of ingredients when } \\
\text { purchasing cosmetics }\end{array}$ & 0.246 & 0.110 & 0.767 & 0.153 & 0.769 \\
\hline $\begin{array}{c}\text { QTY3: I choose the brand which provides good quality } \\
\text { of the products }\end{array}$ & 0.255 & 0.174 & 0.708 & 0.171 & \\
\hline EB1: I pay attention to the brands' societal activities & 0.174 & 0.099 & 0.049 & 0.824 & \\
\hline EB2: I choose brands which behave and act ethically & 0.035 & 0.110 & 0.175 & 0.764 & 0.745 \\
\hline EB3: I choose brands which look after the earth & 0.190 & 0.132 & 0.270 & 0.742 & \\
\hline Sums of Squared Loadings & 2.175 & 2.123 & 2.101 & 2.003 & \\
\hline$\%$ of Variance & 18.123 & 17.695 & 17.512 & 16.688 & \\
\hline Cumulative \% & 18.123 & 35.818 & 53.330 & 70.018 & \\
\hline
\end{tabular}

Extraction Method: Principal Component Analysis. Rotation Method: Varimax with Kaiser Normalization. Rotation converged in 5 iterations.

To investigate the difference in consumer perspectives between the two brands, a non-parametric test was conducted to check the statistical significance between the two sample groups, the results of which are presented in Table 5.

As Table 5 shows, the non-parametric test results indicate that the null hypothesis ('there is no difference between the two groups') was rejected for the four main factors: brand loyalty, quality, communicating sustainability, and ethical behaviour. It can therefore be stated that significant differences in consumer perspectives exist between the two groups in terms of all four of the latent factors.

\subsubsection{Convergent and Discriminant Validity Tests}

Once the process of ascertaining how each item can explain its own construct was completed, the next examination was conducted to identify whether the constructs are valid and reliable. The composite reliabilities (CRs) and average variance extracted (AVE) of the constructs were computed by statistical procedure [83]. These were estimated and are presented in Table 6. Most of the examined values are greater than the accepted lowest values of CR and AVE, which are 0.7 [84] and 0.5 [78]. As Table 6 shows, all values have 
met the relevant requirements, and the overall outcome implies that the constructs are reliable, consistent, and valid [83].

Table 5. Non-parametric test results.

\begin{tabular}{|c|c|c|c|c|}
\hline & Maker & $\mathbf{N}$ & Mean Rank & Sum of Ranks \\
\hline \multirow{3}{*}{ Purchase Intention } & Domestic brand & 400 & 433.92 & 173,570 \\
\hline & International brand & 400 & 367.08 & 146,831 \\
\hline & Total & 800 & & \\
\hline \multirow{3}{*}{ Quality } & Domestic brand & 400 & 364.45 & 145,778 \\
\hline & International brand & 400 & 436.56 & 174,622 \\
\hline & Total & 800 & & \\
\hline \multirow{3}{*}{ Attachment to Brand } & Domestic brand & 400 & 491.86 & 196,744 \\
\hline & International brand & 400 & 309.14 & 123,656 \\
\hline & Total & 800 & & \\
\hline \multirow{3}{*}{ Ethical Behaviour } & Domestic brand & 400 & 419.30 & 167,719 \\
\hline & International brand & 400 & 381.70 & 152,682 \\
\hline & Total & 800 & & \\
\hline Test Statistics & Purchase Intention & Quality & Attachment to Brand & Ethical Behaviour \\
\hline Mann-Whitney U & $66,630.500$ & $65,578.000$ & $43,456.000$ & $72,481.500$ \\
\hline Wilcoxon W & $146,830.500$ & $145,778.000$ & $123,656.000$ & $152,681.500$ \\
\hline $\mathrm{Z}$ & -4.108 & -4.445 & -11.251 & -2.317 \\
\hline Asymp. Sig. (2-tailed) & 0.000 & 0.000 & 0.000 & 0.020 \\
\hline
\end{tabular}

Table 6. Convergent and discriminant validity.

\begin{tabular}{|c|c|c|c|c|c|c|c|c|c|c|}
\hline & $\mathbf{N}$ & Mean & SD & CA & CR & AVE & Brand Loyalty & Quality & $\begin{array}{l}\text { Communicating } \\
\text { Sustainability }\end{array}$ & $\begin{array}{c}\text { Ethical } \\
\text { Behaviour }\end{array}$ \\
\hline Brand loyalty & 800 & 2.775 & 0.862 & 0.836 & 0.828 & 0.616 & 0.785 & & & \\
\hline Quality & 800 & 3.103 & 0.728 & 0.758 & 0.834 & 0.627 & $0.564 * *$ & 0.792 & & \\
\hline $\begin{array}{l}\text { Communicating } \\
\text { Sustainability }\end{array}$ & 800 & 3.202 & 0.842 & 0.769 & 0.810 & 0.588 & $0.504^{* *}$ & $0.338^{* *}$ & 0.767 & \\
\hline Ethical Behaviour & 800 & 3.088 & 0.729 & 0.745 & 0.820 & 0.604 & $0.413 * *$ & $0.446^{* *}$ & $0.319 * *$ & 0.777 \\
\hline
\end{tabular}

Note 1: Values bold on the main diagonal are the square rooted of AVEs; SD is standard deviation; CA is Cronbach alpha; CR is Composite reliability; AVE is average variance standard. Note $2:{ }^{* *}$ means $p<0.1$.

Next, a discriminant validity test was conducted. If the square root of the AVE of each construct, or the average variance (AV), is found to be greater than the Pearson correlation coefficient of that construct with other constructs, then it can be concluded that discriminant validity is confirmed. We computed AVs and Pearson correlation coefficients as demonstrated in Table 6. It was confirmed that the Cronbach's alpha of each construct also indicates that each construct is consistent, as the values of the Cronbach's alpha of each construct are greater than the lowest acceptable value of 0.6 [85]. Constructs so identified are said to be consistent [83]. Correlation analysis is useful for detecting the existence of a covariant among relevant factors that constitute the SEM. As high correlation indicates multicollinearity among variables, the correlation coefficients would ideally not be higher than 0.7 [86]. As shown in Table 6, the factors are confirmed to be suitable for SEM analysis.

\subsection{Structural Equation Modelling}

Using the four factors confirmed via the factor analysis, SEM analysis was conducted on three datasets: 'All', 'Domestic brand', and 'International brand'. Figure 1 presents the SEM results for all samples along with the statistical coefficients of each relational path. As one of the best-fit measures for the research model, the $\chi^{2} /$ degrees of freedom was 2.187 $\left(\chi^{2}=105.004, \mathrm{df}=48\right)$, which met the recommended level of $<5.0$ [85]. Similarly, the other indicators all demonstrated a good fit $(\mathrm{GFI}=0.979$, AGFI $=0.966$, and CFI $=0.984)$ and were all high enough to meet the recommended level of $>0.90$. Meanwhile, the RMSEA (0.039) also met the recommended level of $<0.10$ [85], indicating that the analytical model 
was reliable and suitable for the dataset. Moreover, the R2 value for brand loyalty was relatively high at 0.638 .

The SEM results show that the coefficient of 'quality to brand loyalty' was $0.493^{* * *}$, while that of 'communicating sustainability to brand loyalty' was $0.393^{* * *}$. However, no significant coefficient was found for the 'ethical behaviour to brand loyalty' path. All three of the main factors demonstrated interrelations with significant covariances.

In view of the above, the results of the hypothesis testing can be summarised as follows:

H1 is supported: Quality has a significant impact on consumers' brand loyalty towards cosmetic products.

H2 is supported: Communicating sustainability has a significant impact on consumers' brand loyalty towards cosmetic products.

$\mathrm{H} 3$ is rejected: The ethical behaviour of the producers has no significant impact on consumers' brand loyalty towards cosmetic products.

$\mathrm{H} 4$ is supported: The three main factors for consumer loyalty towards a cosmetics brand are all interrelated.

In particular, as Figure 1 demonstrates, the results of this analysis with respect to H3 have very interesting implications (i.e., that the ethical behaviour of companies has no significant impact on brand loyalty), providing evidence that young Thai consumers, especially those with higher levels of education, do not perceive the CSR activities of cosmetic suppliers as an important factor in brand loyalty. These results may indicate that the younger, more educated generation in Thailand, being located in an emerging market, is in a transition period in terms of market and consumer behaviour, and accordingly that their perceptions of and behaviour towards CSR may differ from those of consumers in developed countries.

\subsection{Comparative Analysis of the Two Brands}

\subsubsection{Domestic Brand}

The SEM model for the 'Domestic brand' demonstrated a good fit with a $\chi^{2} /$ degrees of freedom of $2.131\left(x^{2}=102.309, \mathrm{df}=48\right)$, while the other indices were also above the recommended level of $>0.90(\mathrm{GFI}=0.961$, AGFI $=0.937$ and $\mathrm{CFI}=0.965)$ and $<0.10$ $($ RMSEA $=0.053$ ) [85]. Moreover, the brand loyalty $\mathrm{R} 2$ value was relatively high at 0.679 .

The coefficients of all pathways from two of the factors ('quality' and 'communicating sustainability') to 'brand loyalty' were $0.737^{* * *}$ and $0.206^{* *}$, respectively. Meanwhile, the path between 'ethical behaviour' and 'brand loyalty' demonstrated no significant relationship. The covariances between the three factors indicated significant interrelations, suggesting that while the direct relationship between ethical behaviour and brand loyalty is not significant, all three of the factors could have an indirect impact via influence on the other factors.

\subsubsection{International Brand}

The SEM model for the 'International brand' also indicated good fit levels, with a $\chi^{2} /$ degrees of freedom of $1.852\left(\chi^{2}=88.938, \mathrm{df}=48\right)$, while the other indicators met the recommended level of $>0.90(\mathrm{GFI}=0.965$, AGFI $=0.943$ and $\mathrm{CFI}=0.980)$ and $<0.10$ $($ RMSEA $=0.053)$ [85]. Moreover, the R2 value for brand loyalty was relatively high at 0.635 .

The coefficients of all three paths between 'quality', 'communicating sustainability', 'ethical behaviour' and 'brand loyalty' were all found to be significant, while all covariances among the three factors regarding the relevant hypotheses also demonstrated significant relationships, suggesting that all these factors are interrelated and capable of influencing 'brand loyalty'. Table 7 presents the results for all three models. 
Table 7. Path coefficients among the variables.

\begin{tabular}{|c|c|c|c|c|c|c|c|c|}
\hline \multicolumn{3}{|c|}{ Path } & \multicolumn{2}{|c|}{ All Samples } & \multicolumn{2}{|c|}{ Domestic Brand } & \multicolumn{2}{|c|}{ International Brand } \\
\hline To & & From & $\begin{array}{c}\text { Path } \\
\text { Coefficient }\end{array}$ & $p$ & $\begin{array}{c}\text { Path } \\
\text { Coefficient }\end{array}$ & $p$ & $\begin{array}{c}\text { Path } \\
\text { Coefficient }\end{array}$ & $p$ \\
\hline Brand Loyalty & $<-$ & Quality & 0.493 & $* * *$ & 0.737 & $* * *$ & 0.333 & $* * *$ \\
\hline Brand Loyalty & $<-$ & $\begin{array}{l}\text { Communicating } \\
\text { Sustainability }\end{array}$ & 0.393 & $* * *$ & 0.206 & $* *$ & 0.466 & $* * *$ \\
\hline Brand Loyalty & $<-$ & Ethical Behaviour & 0.072 & 0.13 & -0.044 & 0.610 & 0.124 & $*$ \\
\hline BL1 & $<-$ & Brand Loyalty & 0.831 & 1 fix & 0.827 & 1 fix & 0.832 & 1 fix \\
\hline BL2 & $<-$ & Brand Loyalty & 0.709 & $* * *$ & 0.661 & $* * *$ & 0.754 & $* * *$ \\
\hline BL3 & $<-$ & Brand Loyalty & 0.844 & $* * *$ & 0.812 & $* * *$ & 0.861 & $* * *$ \\
\hline QTY1 & $<-$ & Quality & 0.744 & 1 fix & 0.770 & 1 fix & 0.774 & 1 fix \\
\hline QTTY2 & $<-$ & Quality & 0.683 & $* * *$ & 0.624 & $* * *$ & 0.709 & $* * *$ \\
\hline QTY3 & $<-$ & Quality & 0.717 & $* * *$ & 0.670 & $* * *$ & 0.729 & $* * *$ \\
\hline CS1 & $<-$ & $\begin{array}{l}\text { Communicating } \\
\text { Sustainability }\end{array}$ & 0.662 & 1 fix & 0.465 & 1 fix & 0.733 & 1 fix \\
\hline CS2 & $<-$ & $\begin{array}{l}\text { Communicating } \\
\text { Sustainability }\end{array}$ & 0.740 & $* * *$ & 0.683 & $* * *$ & 0.737 & $* * *$ \\
\hline CS3 & $<-$ & $\begin{array}{l}\text { Communicating } \\
\text { Sustainability }\end{array}$ & 0.778 & $* * *$ & 0.757 & $* * *$ & 0.748 & $* * *$ \\
\hline EB1 & $<-$ & Ethical Behaviour & 0.692 & 1 fix & 0.690 & 1 fix & 0.696 & 1 fix \\
\hline EB2 & $<-$ & Ethical Behaviour & 0.613 & $* * *$ & 0.577 & $* * *$ & 0.643 & $* * *$ \\
\hline EB3 & $<-$ & Ethical Behaviour & 0.798 & $* * *$ & 0.768 & $* * *$ & 0.825 & $* * *$ \\
\hline Quality & $<->$ & Ethical Behaviour & 0.589 & $* * *$ & 0.677 & $* * *$ & 0.551 & $* * *$ \\
\hline Quality & $<->$ & $\begin{array}{l}\text { Communicating } \\
\text { Sustainability }\end{array}$ & 0.440 & $* * *$ & 0.475 & $* * *$ & 0.640 & $* * *$ \\
\hline $\begin{array}{l}\text { Communicating } \\
\text { Sustainability }\end{array}$ & $<->$ & Ethical Behaviour & 0.425 & $* * *$ & 0.451 & $* * *$ & 0.419 & $* * *$ \\
\hline \multirow{8}{*}{ Fit Indexes } & & Chi-square & 105.004 & & 102.309 & & 88.938 & \\
\hline & & df & 48 & & 48 & & 48 & \\
\hline & & $\mathrm{C} / \mathrm{D}$ & 2.188 & & 2.131 & & 1.853 & \\
\hline & & $\mathrm{p}$ & 0.000 & & 0.000 & & 0.000 & \\
\hline & & GFI & 0.979 & & 0.961 & & 0.965 & \\
\hline & & AGFI & 0.966 & & 0.937 & & 0.943 & \\
\hline & & CFI & 0.984 & & 0.965 & & 0.980 & \\
\hline & & RMSEA & 0.039 & & 0.053 & & 0.046 & \\
\hline \multirow{13}{*}{$\mathrm{R} 2$} & & Brand Loyalty & 0.638 & & 0.679 & & 0.635 & \\
\hline & & BL1 & 0.691 & & 0.683 & & 0.693 & \\
\hline & & BL2 & 0.503 & & 0.437 & & 0.569 & \\
\hline & & BL3 & 0.712 & & 0.660 & & 0.742 & \\
\hline & & QTY1 & 0.553 & & 0.593 & & 0.599 & \\
\hline & & QTTY2 & 0.466 & & 0.390 & & 0.503 & \\
\hline & & QTY3 & 0.514 & & 0.449 & & 0.531 & \\
\hline & & CS1 & 0.438 & & 0.216 & & 0.537 & \\
\hline & & CS2 & 0.547 & & 0.466 & & 0.544 & \\
\hline & & CS3 & 0.606 & & 0.573 & & 0.559 & \\
\hline & & EB1 & 0.478 & & 0.477 & & 0.485 & \\
\hline & & EB2 & 0.375 & & 0.333 & & 0.414 & \\
\hline & & EB3 & 0.636 & & 0.590 & & 0.680 & \\
\hline
\end{tabular}

Note 1: df: degree of freedom, C/D: Chi-square/df, p: provability, GFI: Goodness of fit index, AGFI: Adjusted goodness of fit index, CFI: Comparative fit index, RMSEA: Root mean square error of approximation. Note 2 : Squared multiple correlations (SMC) in SPSS AMOS was used as R2. Note 3: ${ }^{* * *}$ means $p<0.001$; ${ }^{* *}$ means $p<$ $0.01 ;{ }^{*}$ means $p<0.05$ Note 4: 1 fix means regression weight is fixed as 1 .

\subsubsection{Overview of the Comparative Analysis}

The Thai consumers' perspectives on the 'Domestic brand' in terms of 'quality' and 'brand loyalty' were found to have the highest significance $\left(0.737^{* * *}\right)$, while 'communicating sustainability' and 'brand loyalty' demonstrated a weaker correlation $\left(0.206^{* *}\right)$. In terms of the 'International brand', all three factors had a significant impact on 'brand loyalty', while the impact of 'quality' was weaker than that for the 'Domestic brand'.

In the 'All' sample, two of the three latent factors (i.e., not ethical behaviour) were found to have a significant effect on brand loyalty, while no such significant relationship was found for ethical behaviour. This phenomenon can be interpreted to suggest that consumers in Thailand, as an emerging country, already pay attention to marketing communications 
about the quality and sustainability of cosmetics and judge these factors as triggers for purchase and repeat business. The three observables of communicating sustainability, or CS ('Attachment to brand with $\mathrm{CS}^{\prime}$; 'Feeling resonance with CS'; 'CS is helpful for nurturing my loyalty') are all significant components of the latent factor CS. On the other hand, ethical behaviour (EB), which consists of three observables ('Social activities'; 'Acting ethically'; 'Looking after the earth'), has not yet been grasped and evaluated with a clear awareness or recognised as a reference factor in product purchasing (see Figure 1 for all samples.) Further details are presented in Table 7.

In light of Table 7, the significance of ethical behaviour is found to differ between domestic and international brands. In other words, the relationship between domestic brands and H4 is not supported. Thai consumers may change the focus of their purchase decision depending on the product's country of origin. This suggests that consumers in emerging countries will pay closer attention to manufacturers' ethical behaviour in the future and allow this information to influence their brand loyalty.

Moreover, H4 'covariance relationship between the three latent factors', was found to be significant; thus, although no direct relationship between ethical behaviour and brand loyalty was identified, it is possible that ethical behaviour influences brand loyalty via the other two antecedents.

To triangulate this finding, the four factors for the two brands were examined based on the scores for the confirmed factors (Figure 2).

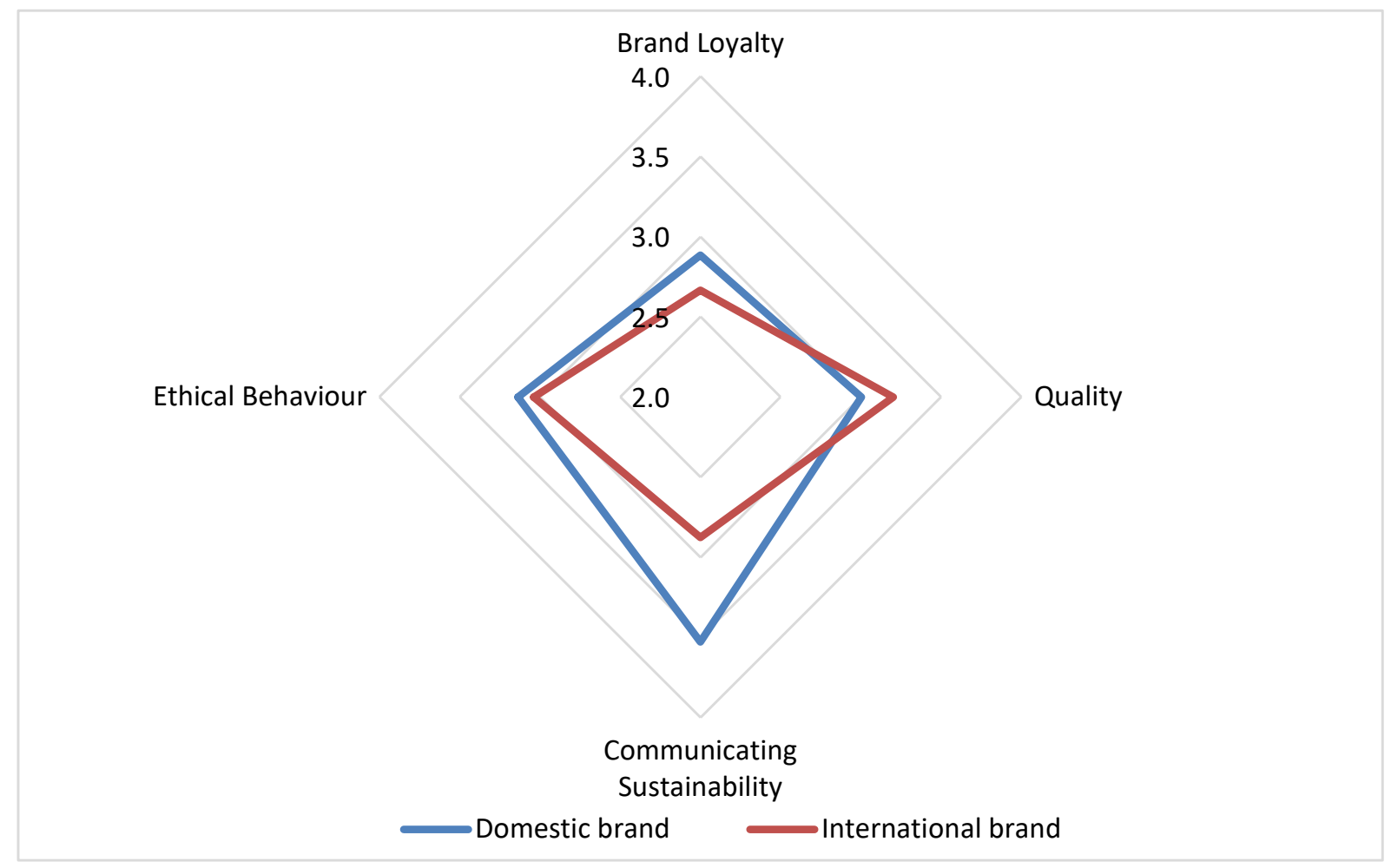

Figure 2. The four latent factors for domestic and international brands.

As Figure 2 shows, significantly different perspectives can be observed between the two brands. The most substantial difference was found for 'communicating sustainability', which indicates that Thai consumers are more responsive to the domestic brands' marketing strategies for communicating sustainability than those of the international brands.

The finding of this study could fill the gap in the existing research. For example, [87] conducted an experiment to test whether and how CSR marketing influences consumer behaviour and found that the influence increases when the psychological distance is close. On the other hand, [88] attempted to examine the main and interaction effects of 
CSR involvement, brand naming and pricing on consumer purchase intentions using a $2 \times 2 \times 2$ experimental design. In the high price range, CSR involvement had a strong effect on purchase intentions for products with foreign brand names; in the low price range, CSR involvement had a significant effect regardless of brand name. These authors concluded that there is no significant effect of CSR involvement regardless of the brand name. Among more recent studies, for example, [89] examined the mediating effect of CSR factors on Gen-Y consumer behaviour and found a direct relationship between perceptions of value compatibility and consumer perceptions of CSR.

Thus, while several studies using Thai consumer datasets have examined the impact of CSR-based marketing on consumers' willingness to purchase, few studies have discussed the differences in consumer behaviour due to CSR. Among the valuable existing studies, for example, [7] examine the interaction between CSR and branding in the context of an emerging economy, using data from a survey of the attitudes of residents of the Lima metropolitan area in Peru, and conducted an analysis using the stimulus-organisation-response (SOR) model. The study argues that CSR effectively acts as a stimulus for consumers to identify and associate with a brand. However, these authors also note that given the impact of emerging economies on the global economy, alongside the magnitude of the impact of CSR initiatives on consumer behaviour in those countries, there is far too little research on the subject.

\section{Conclusions, Implications and Limitations}

\subsection{Theoretical Contributions}

This study has revealed and validated three antecedent factors, demonstrating that they are useful in examining consumers' loyalty towards branded cosmetic products. Among the three factors, the 'ethical behaviour of the producers' factor was found to have a non-significant impact (for all samples and 'Domestic brand') and the weakest impact on brand loyalty for 'International brand' products. Meanwhile, 'quality' had the most significant impact on brand loyalty, especially for the 'Domestic brand', indicating that domestic brands should focus on quality to develop customer loyalty.

Interesting outcomes were found for the 'communicating sustainability' and 'ethical behaviour of the producers' factors, with the former having a significant impact on brand loyalty across all samples and the latter demonstrating no significant impact and having the weakest impact on brand loyalty. As numerous scholars have indicated, communicating sustainability and ethical behaviour are important elements of devising marketing strategies to attract customers [90-92]. Moreover, ensuring brand loyalty is evidently another target for firms aiming to be more competitive and sustainable $[35,93,94]$.

Here, while we analysed the impact of the aforementioned factors within the context of business sustainability strategies, the present conclusions must be further verified using a larger dataset in order to develop robust implications for both theory and practice. Given that, due to the nature of emerging markets, the current snapshot of consumer perspectives and behaviours in these markets could well change over time, it will be crucial to conduct further research that extends beyond the established international knowledge and experience of consumer behaviour $[95,96]$.

Scale development and validation within an emerging market context have been confirmed in this study, while consumer perceptions and behaviours within a Thai market context were found to exhibit different characteristics from the oft-discussed Western markets. Therefore, the authors acknowledge that the present research findings will help to identify the changes between emerging markets and can also help to reveal the differences between emerging and developed markets.

However, our finding that the impact of sustainable communication and ethical values on consumer loyalty is non-significant stands in stark contrast to the findings of previous studies working within different contexts. Further research into this discrepancy is undoubtedly required. Another issue that merits further investigation is as follows: since the data for this study were largely collected from a sample of highly educated 
people (university degree or above) living in the capital city of Bangkok, the findings of a non-significant influence of CSR and ethical behaviour of producers on the purchase intentions of Thailand's highly educated, urban-dwelling Gen-Y cohort should be explored in more depth.

\subsection{Practical Contribution}

This study makes several novel practical contributions. The first is that it was based on a relatively large sample of well-educated young consumers $(93.5 \%$ of the total sample are university graduates or have attained postgraduate qualifications), making it well-suited to assessing the younger generation's perspectives and attitudes.

The first significant output from the study is that it demonstrates that young Thai consumers tend not to pay attention to the ethical behaviour displayed by businesses when they make purchasing decisions in the cosmetics market. This brings into focus an issue that has not been substantially addressed by previous research into buying behaviour in emerging markets generally and among younger Thai consumers specifically: in short, at present, these consumers do not give much thought to the ethical behaviour of cosmetic manufacturers, a finding that should be taken into account when formulating marketing strategies for cosmetic companies.

On the other hand, these results also highlight the need to consider differences in consumer attitudes depending on whether the brand is international or domestic, so as to determine which channels can be used to gain their support and how current consumer behaviour is likely to change over time. In particular, the results clearly suggest that we should carefully monitor the ways in which current consumer behaviour changes over time and reflect this in our business strategy.

Of particular relevance is the development of a practical measure of the determinants of consumer purchasing behaviour in emerging markets. The results of an empirical investigation using this measure revealed that consumer awareness and behaviour differ depending on the brand's country of origin. We believe that the results of this study provide a valuable basis for the development of future corporate strategies for communicating with consumers about sustainability.

\subsection{Limitations}

As discussed at the beginning of this study, the analysis is based on a sample of young people, most of whom are highly educated, who represent the driving force behind Thailand's economy owing to their socio-economic situation. We thus cannot simply generalise these findings to Thai consumers in general. The authors are well aware that results based on such a distinct dataset must be tested in future on a broader dataset and discussed from a higher perspective.

As noted, the results obtained here stand in contrast to the findings of international research, which has shown that younger generations are more likely than other generations to engage in ethical business practices and to pay attention to the CSR strategies of product and service providers in their purchasing behaviour. In other words, H3 is not supported, which may suggest that the preferences of young Thai consumers are still undergoing a transition due to their status as participants in an emerging market. In light of the need to promote sustainable development and responsible manufacturing and consumption practices, further related research, accumulation of knowledge and policy implications should be pursued.

\subsection{Recommendations and Future Work}

As noted above, the findings of this study should be re-examined in more depth; however, the present discussion with its basis in a Thai dataset will unquestionably shed some light on the current research agenda. Nonetheless, further and more comprehensive investigations into consumers' perspectives on and attitudes towards different brands should be conducted in the future. The notion is that a good brand image that incorporates 
ethical values and communicates sustainable efforts will go some way towards achieving consumer loyalty. It is the responsibility of social scientists to observe and track consumers changing perspectives and attitudes toward sustainable and ethical business strategies, as this will aid them to evaluate and recommend how effective marketing plans can be formulated within competitive markets.

In future studies, the scales and measurements developed herein will be validated and tested for other industrial sectors (e.g., food, apparel, and other commodities) and in different markets with varied values and histories in order to expand our contribution to both theory and practice.

Author Contributions: H.O. conducted the literature review and conceived the study. Y.Y. and H.O. built the data extraction file and both collaboratively performed data extraction. Both authors analysed the data. H.O. supervised the process, and found and decided the company that is capable of conducting the questionnaire survey equivalent to the one implemented in Japan. Y.Y. developed the English draft of the web questionnaire and contributed to review relevant literature for each observed variable. Both authors contributed extensively to this work, interpreted the data, contributed substantially to the writing and revision of the manuscript, and read and approved the final version of the manuscript. All authors have read and agreed to the published version of the manuscript.

Funding: This research received no external funding.

Institutional Review Board Statement: The study was conducted in accordance with the policy of Declaration of Helsinki, and approved by the Research Ethics Sub-Committee of Faculty of Society and Industry, the Open University of Japan. The research ethics and protection of personal information were also in accordance with the "Guidelines for the Protection of Personal Information" of the Japan Society of Education. Date of approval, 15 October 2020.

Informed Consent Statement: Informed consent was obtained from all subjects involved in the study.

Data Availability Statement: The data are not publicly available due to this data was obtained under conditions that are not intended to be published.

Acknowledgments: The authors thank all the survey respondents for their participation in the study.

Conflicts of Interest: The authors declare no conflict of interest.

\section{References}

1. Amberg, N.; Fogarassy, C. Green Consumer Behavior in the Cosmetics Market. Resources 2019, 8, 137. [CrossRef]

2. Ghazali, E.; Soon, P.C.; Mutum, D.S.; Nguyen, B. Health and Cosmetics: Investigating Consumers' Values for Buying Organic Personal Care Products. J. Retail. Consum. Serv. 2017, 39, 154-163. [CrossRef]

3. Jahn, J.; Brühl, R. Can Bad News Be Good? On the Positive and Negative Effects of Including Moderately Negative Information in CSR Disclosures. J. Bus. Res. 2019, 97, 117-128. [CrossRef]

4. Lee, Y.H.; Chen, S.L. Effect of Green Attributes Transparency on WTA for Green Cosmetics: Mediating Effects of CSR and Green Brand Concepts. Sustainability 2019, 11, 5258. [CrossRef]

5. Rogiers, V. Animal-Free Cosmetics in Europe. In The History of Alternative Test Methods in Toxicology; Academic Press: New York NY, USA, 2019; pp. 157-166.

6. Oe, H.; Yamaoka, Y. A Study of Value Perceptions and Purchase Attitudes towards Sweets Products in Thailand. In Proceedings of the Annual Meeting of the Thai Society of Japan, Tokyo, Japan, 10 July 2021.

7. Cambra-Fierro, J.J.; Flores-Hernández, J.A.; Pérez, L.; Valera-Blanes, G. CSR and Branding in Emerging Economies: The Effect of Incomes and Education. Corp. Soc. Responsib. Environ. Manag. 2020, 27, 2765-2776. [CrossRef]

8. Oe, H.; Yamaoka, Y. Consumer Perceptions of Corporate Social Responsibility and Its Relationship with Consumer Behaviour: Scale Development and Validation in an Emerging Market Context. J. Cust. Behav. No. 19 2020, 3, 202-225. [CrossRef]

9. Sartamorn, S. Hybrid Social Media Marketing: How Augmented Reality Enhance Emotional Value and Persuasive Effect from Thai Consumers toward Organic Food Sector in Thailand. In Proceedings of the Annual Meeting of the Thai Society of Japan, Tokyo, Japan, 10 July 2021.

10. Hiramatsu, H. Reconsidering Tom Yanti's "Kookam" (The Remnants of Maenam): Thailand's Views on Gender and Nation Behind the Romance. CIRAS Discuss. Pap. 2020, 91, 55-66.

11. El-Bassiouny, N.; Darrag, M.; Zahran, N. Corporate Social Responsibility (CSR) Communication Patterns in an Emerging Market: An Exploratory Study. J. Organ. Change Manag. 2018, 31, 795-809. [CrossRef]

12. Gunawan, S.; Budiarsi, S.Y.; Hartini, S. Authenticity as a Corporate Social Responsibility Platform for Building Customer Loyalty. Cogent Bus. Manag. 2020, 7, 1775023. [CrossRef] 
13. Yeo, A.C.; Carter, S. Consumer Perception towards Corporate Social Responsibility Practices: A Study of the Malaysian Banking Sector. Int. J. Mob. Learn. Organ. 2020, 14, 307-321. [CrossRef]

14. Worldbank.org. Thailand Data: Washington DC, USA. 2021. Available online: https://data.worldbank.org/country/thailand (accessed on 21 June 2021).

15. ILOSTAT. The Leading Source of Labour Statistics; ILOSTAT: Geneva, Switzerland, 2021. Available online: https:/ /ilostat.ilo.org/ (accessed on 21 June 2021).

16. Supply Chain movement. MES Improves Supply Chain Visibility and Collaboration; Supply Chain Movement: London, UK, 2018 Available online: https:/ /www.supplychainmovement.com/ms-improves-supply-chain-visibility-collaboration/ (accessed on 2 August 2021).

17. Lores, M.; Llompart, M.; Alvarez-Rivera, G.; Guerra, E.; Vila, M.; Celeiro, M.; Lamas, P.; Garcia-Jares, C. Positive Lists of Cosmetic Ingredients: Analytical Methodology for Regulatory and Safety Controls-A Review. Anal. Chim. Acta 2016, 915, 1-26. [CrossRef]

18. Park, J. Framework for Sentiment-Driven Evaluation of Customer Satisfaction with Cosmetics Brands. IEEE Access 2020, 8 , 98526-98538. [CrossRef]

19. Montagnini, F.; Maggioni, I.; Sebastiani, R. Emerging Segments in Ethical Consumption: Young Adults and Cosmetics. In Looking Forward, Looking Back: Drawing on the Past to Shape the Future of Marketing; Springer: Cham, IL, USA, 2016; pp. $206-215$.

20. Sorum, N. Ethical Consumption Applications as Failed Market Innovations: Exploring Consumer (non) Acceptance of 'Quasi' Market Devices. J. Cult. Econ. 2020, 13, 91-113. [CrossRef]

21. Marks and Spencer. MES Interactive map; Marks and Spencer: London, UK, 2020. Available online: https://interactivemap. marksandspencer.com/?sectionPID =56c359428b0c1e3d3ccdf022 (accessed on 13 June 2021).

22. Arce-Calero, L.; Gallegos-Florez, K.; Sotelo-Ruffo, J.; Ramos-Palomino, E. Improvement Proposal to Raise Service Level in a Cosmetics Retail Company. In 2019 Congreso Internacional de Innovación y Tendencias en Ingenieria (CONIITI); IEEE: Toulouse, France, 2019; pp. 1-5.

23. Renner, G.; Audebert, F.; Burfeindt, J.; Calvet, B.; Caratas-Perifan, N.; Leal, M.E.; Gorni, R.; Long, A.; Meredith, E.; O'Sullivan, Ú. Cosmetics Europe Guidelines on the Management of Undesirable Effects and Reporting of Serious Undesirable Effects from Cosmetics in the European Union. Cosmetics 2017, 4, 1. [CrossRef]

24. Chinomona, R.; Maziriri, E.T. The Influence of Brand Awareness, Brand Association and Product Quality on Brand Loyalty and Repurchase Intention: A Case of Male Consumers for Cosmetic Brands in South Africa. J. Bus. Retail. Manag. Res. 2017, 12, 143-154. [CrossRef]

25. Hwang, J.K.; Kim, E.J.; Lee, S.M.; Lee, Y.K. Impact of Susceptibility to Global Consumer Culture on Commitment and Loyalty in Botanic Cosmetic Brands. Sustainability 2021, 13, 892. [CrossRef]

26. Kassim, N.M.; Jamaludin, N.A.B.; Shaari, Z.H. Investigating the Brand Loyalty of Domestic Cosmetic in an Emerging Marke't. In SHS Web of Conferences; EDP Sciences: Les Ulis, France, 2021; Volume 124, p. 05001.

27. Pearce, J. Expanding the Consumer Bill of Rights for Material Ingredients. Mater. Today 2018, 21, 197-198. [CrossRef]

28. Vorster, A. The Effective Compounding of Botanical and Scientific Ingredients. S. Afr. Pharm. Cosmet. Rev. 2018, $45,32-33$.

29. Chaovalit, P. Factors Influencing Cosmetics Purchase Intention in Thailand: A Study on the Relationship of Credibility and Reputation with in Persuasive Capabilities of Beauty Bloggers. AU-GSB e-JOURNAL 2014, 7. Available online: http://www. assumptionjournal.au.edu/index.php/AU-GSB/article/view/445 (accessed on 26 December 2021).

30. Spiteri Cornish, L. Ethical Consumption or Consumption of Ethical Products? An Exploratory Analysis of Motivations behind the Purchase of Ethical Products. NA-Adv. Consum. Res. 2013, 41. Available online: https://www.acrwebsite.org/volumes/v4 1/acr_v41_14861.pdf (accessed on 26 December 2021).

31. Taghipour, A.; Loh, A. A Study of the Factors Related to Purchase Intention of Cosmetics Customers in Thailand. PEOPLE Int. J. Soc. Sci. 2017, 3, 1942-1946. [CrossRef]

32. Boateng, H.; Kosiba, J.P.; Adam, D.R.; Ofori, K.S.; Okoe, A.F. Examining Brand Loyalty from an Attachment Theory Perspective. Mark. Intell. Plan. 2020, 38, 470-494. [CrossRef]

33. Gómez-Suárez, M. Examining Customer-Brand Relationships: A Critical Approach to Empirical Models on Brand Attachment, Love, and Engagement. Adm. Sci. 2019, 9, 10. [CrossRef]

34. Conrad, C.; Thompson, M.E. The New Brand Spirit: How Communicating Sustainability Builds Brands, Reputations and Profits; CRC Press: Boca Raton, FL, USA, 2016.

35. Ranjan, S.; Sahu, T. Impct of Ethical Advertisement on Customer Loyalty, International Journal of Economics. Commer. Manag. 2014, 2, 1-8.

36. Shanahan, T.; Tran, T.P.; Taylor, E.C. Getting to Know You: Social Media Personalization as a Means of Enhancing Brand Loyalty and Perceived Quality. J. Retail. Consum. Serv. 2019, 47, 57-65. [CrossRef]

37. Chung, D.H.; Sung, J.H. A Study on CSR Types of Cosmetic Companies to Gain Customer Loyalty of Product Brand. J. Korea Contents Assoc. 2019, 19, 184-192.

38. Siano, A.; Conte, F.; Amabile, S.; Vollero, A.; Piciocchi, P. Communicating Sustainability: An Operational Model for Evaluating Corporate Websites. Sustainability 2016, 8, 950. [CrossRef]

39. Zhou, Z.; Zhang, Q.; Su, C.; Zhou, N. How Do Brand Communities Generate Brand Relationships? Intermediate Mechanisms. J. Bus. Res. 2012, 65, 890-895. [CrossRef] 
40. Wirtz, J.; Ad Ambtman Bloemer, J.; Horváth, C.; Ramaseshan, B.; Jvd Klundert Canli ZGand Kandampully, J. Managing Brands and Customer Engagement in Online Brand Communities. J. Serv. Manag. 2013, 24, 223-244. [CrossRef]

41. Kong, H.M.; Witmaier, A.; Ko, E. Sustainability and Social Media Communication: How Consumers Respond to Marketing Efforts of Luxury and Non-Luxury Fashion Brands. J. Bus. Res. 2021, 131, 640-651. [CrossRef]

42. Jung, J.; Kim, S.J.; Kim, K.H. Sustainable Marketing Activities of Traditional Fashion Market and Brand Loyalty. J. Bus. Res. 2020, 120, 294-301. [CrossRef]

43. Wongprawmas, R.; Canavari, M. Consumers' Willingness-to-Pay for Food Safety Labels in an Emerging Market: The Case of Fresh Produce in Thailand. Food Policy 2017, 69, 25-34. [CrossRef]

44. Wirunphan, P.; Ussahawanitchakit, P. Brand Competency and Brand Performance: An Empirical Research of Cosmetic Businesses and Health Products Business in Thailand. Bus. Manag. Rev. 2016, 7, 329-338.

45. Grappe, C.G.; Lombart, C.; Louis, D.; Durif, F. Not Tested on Animals: How Consumers React to Cruelty-Free Cosmetics Proposed by Manufacturers and Retailers? Int. J. Retail. Distrib. Manag. 2021, 49, 1532-1553. [CrossRef]

46. Jakubanecs, A.; Supphellen, M.; Fedorikhin, A.; Haugen, H.M.; Sivertstøl, N. Elicitation of Salient Brand Emotions in Western and East Asian Markets: The Role of Elicitation Context. Int. J. Mark. Res. 2019, 61, 518-533. [CrossRef]

47. Sthienrapapayut, T.; Moschis, G.P.; Mathur, A. Using Gerontographics to Explain Consumer Behaviour in Later Life: Evidence from a Thai Study. J. Consum. Mark. 2018, 35, 317-327. [CrossRef]

48. Blackwell, R.D.; Miniard, P.W.; Engle, J.F. Consumer Behaviour, 10th ed.; Thomson Higher Education: Belmont, CA, USA, 2006.

49. Ahn, J.; Wong, M.L.; Kwon, J. Different Role of Hotel CSR Activities in the Formation of Customers' Brand Loyalty. Int. J. Qual. Serv. Sci. 2020, 12, 337-353. [CrossRef]

50. Aydın, H. Consumer Perceptions and Responsiveness toward csr Activities: A Sectoral Outlook. In Ethics, Social Responsibility and Sustainability in Marketing; Springer: Singapore, 2019; pp. 45-63.

51. Ozdemir, S.; Zhang, S.; Gupta, S.; Bebek, G. The Effects of Trust and Peer Influence on Corporate Brand-Consumer Relationships and Consumer Loyalty. J. Bus. Res. 2020, 117, 791-805. [CrossRef]

52. Park, E.; Kim, K.J.; Kwon, S.J. Corporate Social Responsibility as a Determinant of Consumer Loyalty: An Examination of Ethical Standard, Satisfaction, and Trust. J. Bus. Res. 2017, 76, 8-13. [CrossRef]

53. Abdullah, R.; Malik, E.; Pratiwi, E.T.; Abdullah, L.O.D.; Sulili, A. Influence of Corporate Social Responsibility on Company Performance. In IOP Conference Series: Earth and Environmental Science; IOP Publishing: Bristol, UK, 2019; Volume 235, p. 012004.

54. Dahlmann, F.; Stubbs, W.; Raven, R.; de Albuquerque, J.P. The 'Purpose Ecosystem': Emerging Private Sector Actors in Earth System Governance. Earth Syst. Gov. 2020, 4, 100053. [CrossRef]

55. O'Faircheallaigh, C.; Ali, S. (Eds.) Earth Matters: Indigenous Peoples, the Extractive Industries and Corporate Social Responsibility; Routledge: London, UK, 2017.

56. Gilal, F.G.; Zhang, J.; Gilal, R.G.; Gilal, N.G. Integrating Intrinsic Motivation into the Relationship between Product Design and Brand Attachment: A Cross-Cultural Investigation Based on Self-Determination theory. Eur. J. Int. Manag. 2020, 14, 1-27. [CrossRef]

57. Franzoi, S.L. Psychology: A Discovery Experience; South-Western, Cengage Learning: Mason, OH, USA, 2011.

58. Briliana, V.; Mursito, N. Exploring Antecedents and Consequences of Indonesian Muslim youths' Attitude towards Halal Cosmetic Products: A Case Study in Jakarta. Asia Pac. Manag. Rev. 2017, 22, 176-184. [CrossRef]

59. Asgari, O.; Hosseini, M.S. Exploring the Antecedents Affecting Attitude, Satisfaction, and Loyalty towards Korean Cosmetic Brands. J. Distrib. Sci. 2015, 13, 45-70. [CrossRef]

60. Sadiq, M.; Adil, M.; Paul, J. An Innovation Resistance Theory Perspective on Purchase of Eco-Friendly Cosmetics. J. Retail. Consum. Serv. 2021, 59, 102369. [CrossRef]

61. Akbari, M.; Kazemi, R.; Haddadi, M. Relationship Marketing and Word-of-Mouth Communications: Examining the Mediating Role of Customer Loyalty. Mark. Branding Res. 2016, 3, 63-74. [CrossRef]

62. Liu, W.K.; Lee, Y.S.; Hung, L.M. The Interrelationships among Service Quality, Customer Satisfaction, and Customer Loyalty: Examination of the Fast-Food Industry. J. Foodserv. Bus. Res. 2017, 20, 146-162. [CrossRef]

63. Priyo, J.S.; Mohamad, B.; Adetunji, R.R. An Examination of the Effects of Service Quality and Customer Satisfaction on Customer Loyalty in the Hotel Industry. Int. J. Supply Chain. Manag. 2019, 8, 653-663.

64. Zgirskas, A.; Ruževičius, J.; Ruželè, D. Benefits of Quality Management Standards in Organizations. Standards 2021, 1, 154-166. [CrossRef]

65. Chan, Y.Y.; Mansori, S. Factor that Influences Consumers' Brand Loyalty towards Cosmetic Products. J. Mark. Manag. Consum. Behav. 2016, 1, 12-29.

66. Shalehah, A.; Trisno, I.L.O.; Moslehpour, M.; Cor, P.K.L. The Effect of Korean Beauty Product Characteristics on Brand Loyalty and Customer Repurchase Intention in Indonesia. In Proceedings of the 2019 16th International Conference on Service Systems and Service Management (ICSSSM), Shenzhen, China, 13-15 July 2019; IEEE: Toulouse, France, 2019; pp. 1-5.

67. Taylor, S.A.; Celuch, K.; Goodwin, S. The Importance of Brand Equity to Customer Loyalty. J. Prod. Brand Manag. 2004, 13, 217-227. [CrossRef]

68. Villarejo-Ramos, A.F.; Sanchez-Franco, M.J. The Impact of Marketing Communication and Price Promotion on Brand Equity. J. Brand Manag. 2005, 12, 431-444. [CrossRef] 
69. Vinh, T.T.; Phuong, T.T.K. An Empirical Study Examining a Mediated Moderated Model of Perceived Price Fairness, Brand Equity and Purchase Intention. Int. J. Adv. Res. Econ. Financ. 2020, 2, 44-59.

70. Del Rio, A.B.; Vazquez, R.; Iglesias, V. The Effects of Brand Associations on Consumer Response. J. Consum. Mark. 2001, 18, 410-425. [CrossRef]

71. Rizvi, W.H.; Memon, S.; Dahri, A.S. Brand Experience Clustering and Depiction of Brand Satisfaction, Brand Loyalty and Emotional Confidence. Found. Manag. 2020, 12, 111-124. [CrossRef]

72. Saunders, M.; Lewis, P.; Thornhill, A. Research Methods for Business Students; Prentice Hall: New York, NY, USA, 2009.

73. Bryman, A.; Bell, E. Business Research Methods, 4th ed.; Oxford University Press: Oxford, UK, 2015.

74. Brislin, R.W. Translation and Content Analysis of Oral and Written Material. In Handbook of Cross-Cultural Psychology; Triandis, H.C., Berry, J.W., Eds.; Allyn and Bacon: Boston, MA, USA, 1980; Volume 2: Methodology.

75. Ruvio, A.; Shoham, A. Innovativeness, Exploratory Behavior, Market Mavenship, and Opinion Leadership: An Empirical Examination in the Asian Context. Psychol. Mark. 2007, 24, 703-722. [CrossRef]

76. Karem Kolkailah, S.; Abou Aish, E.; El-Bassiouny, N. The Impact of Corporate Social Responsibility Initiatives on Consumers' Behavioural Intentions in the Egyptian Market. Int. J. Consum. Stud. 2012, 36, 369-384. [CrossRef]

77. Hair, J.F.; Ringle, C.M.; Sarstedt, M. PLS-SEM: Indeed, a Silver Bullet. J. Mark. Theory Pract. 2011, 19, 139-152. [CrossRef]

78. Leontitsis, A.; Pagge, J. A Simulation Approach on Cronbach's Alpha Statistical Significance. Math. Comput. Simul. 2007, 73, 336-340. [CrossRef]

79. Yamamoto, K.; Onodera, T. Structural Equation Modelling by Amos and Case Analyses; Nakanishiya Syuppan: Kyoto, Japan, 1999.

80. Podsakoff, P.M.; MacKenzie, S.B.; Lee, J.-Y.; Podsakoff, N.P. Common Method Biases in Behavioral Research: A Critical Review of the Literature and Recommended Remedies. J. Appl. Psychol. 2003, 88, 879-903. [CrossRef]

81. Podsakoff, P.M.; MacKenzie, S.B.; Podsakoff, N.P. Sources of Method Bias in Social Science Research and Recommendations on How to Control it. Annu. Rev. Psychol. 2012, 63, 539-569. [CrossRef]

82. Tavakol, M.; Dennick, R. Making Sense of Cronbach's Alpha. Int. J. Med. Educ. 2011, 2, 53-55. [CrossRef]

83. Fornell, C.; Larcker, D.F. Evaluating Structural Equation Models with Unobservable Variables and Measurement Error. J. Mark. Res. 1981, 18, 39-50. [CrossRef]

84. Urbach, N.; Ahlemann, F. Structural Equation Modeling in Information System Research Using Partial Least Squares. J. Inf. Technol. Theory Appl. 2010, 11, 5-40.

85. Hair, J.F.; Jr Black, W.C.; Babin, B.J.; Anderson, R.E. Multivariate Data Analysis; Prentice Hall: Upper Saddle River, NJ, USA, 2010.

86. Ratner, B. The Correlation Coefficient: Its Values Range between $+1 /-1$, or Do They? J. Target. Meas. Anal. Mark. 2009, 17, 139-142. [CrossRef]

87. Lii, Y.S.; Wu, K.W.; Ding, M.C. Doing Good Does Good? Sustainable Marketing of CSR and Consumer Evaluations. Corp. Soc. Responsib. Environ. Manag. 2013, 20, 15-28. [CrossRef]

88. Boonpattarakan, A. An Experimental Design to Test the Main and Interaction Effects of CSR Involvement, Brand Naming, and Pricing on Purchase Intentions in Thailand. Int. J. Bus. Manag. 2012, 7, 62. [CrossRef]

89. Tantivejakul, N. The Mediating Role of CSR on Corporate Reputation and Behavioral Intention: A Study of Thai Gen Y Consumers. Soc. Sci. Asia 2020, 6, 13-29.

90. Alevizou, P.J.; Henninger, C.E.; Spinks, C. Communicating Sustainability Practices and Values: A Case Study Approach of a Micro-Organisation in the UK. Int. J. Bus. Glob. 2019, 22, 37-52. [CrossRef]

91. Lohr, S. First, Make Money. Also, Do Good; The New York Times: New York, NY, USA, 2011.

92. Ott, H.; Wang, R.; Bortree, D. Communicating Sustainability Online: An Examination of Corporate, Nonprofit, and University Websites. Mass Commun. Soc. 2016, 19, 671-687. [CrossRef]

93. Murugan, M.S.; Shanthi, R.M. Issues Relating to Purchase and Post Purchase Behaviour. J. Manag. Sci. 2012,2 , 52-54.

94. Peng, M.Y.P. Expressive Brand Relationship, Brand Love and Brand Loyalty for Table PC: Building for Sustainable Brand. Front. Psychol. 2020, 11, 231-240.

95. Borg, E.; Hooker, B. Epistemic Virtues Versus Ethical Values in the Financial Services Sector. J. Bus. Ethics 2019, 155, 17-27. [CrossRef]

96. Oe, H.; Sunpakit, P.; Yamaoka, Y.; Liang, Y. An Exploratory Study of Thai Consumers' Perceptions of "Conspicuousness": A Case of Luxury Handbags. J. Consum. Mark. 2018, 35, 601-612. [CrossRef] 